\title{
Health impacts of the 2005 flood events on feedlot farm families in southern Alberta, Canada
}

\author{
M. P. Acharya ${ }^{1}$, R. G. Kalischuk ${ }^{1}$, K. K. Klein ${ }^{1}$ \& H. Bjornlund ${ }^{1,2}$ \\ ${ }^{I}$ Department of Economics and School of Health Sciences, \\ University of Lethbridge, Canada \\ ${ }^{2}$ University of South Australia, Australia
}

\begin{abstract}
In the summer of 2005, southern Alberta received heavy rainfall that led to extensive flooding. Four separate flooding events severely affected several rural communities, roads, bridges, and businesses within the region; specifically, the flooding affected farm families living on Canada's largest feedlot operations in the area. This article explores the health-related impacts of the 2005 flood events on families who reside on feedlot farms in southern Alberta. Utilizing random sampling, an in-person survey was conducted between September and December 2005 with 33 affected feedlot farm families living in the Lethbridge Northern Irrigation District, home of the greatest number of large beef feedlot operations in Canada. Three percent of participants (and 12\% of their family members) reported flood-related health problems. However, $63 \%$ of participants (and 58\% of their family members) reported flood-related mental health problems, and $40 \%$ (and $24 \%$ of family members) indicated that they experienced isolation and helplessness. Only $9 \%$ of the participants accessed health services. Most participants reported that their communities were more helpful in dealing with their flood-related health problems than were public and service delivery sectors. A majority $(91 \%)$ of participants reported that their family was helpful, followed by friends $(64 \%)$, neighbors $(42 \%)$, church $(39 \%)$, and employees $(36 \%)$. Among the affected feedlot farm families, a small percentage experienced physical health problems but a much larger percentage had mental health problems. However, only a few utilized health care services. This information will be important to health care leaders and policy makers as they plan and develop efficient and effective health care support for farm families exposed to flooding events.

Keywords: 2005 flood events, feedlot farm families, health impacts, southern Alberta, Canada, health care services, mental health problems, isolation and helplessness.
\end{abstract}




\section{Introduction}

Southern Alberta in western Canada, a semi-arid region with high summer temperatures and low rainfall $[1,2]$, in 2005 experienced the worst and costliest natural disaster in the history of that province [3-6]. Three major floods in the month of June and further torrential rainfall from September 9 to 11 produced $534 \mathrm{~mm}$ of rain by the end of September $[4,7,8]$. In terms of precipitation and flood-related human fatalities, this region's 2005 flooding is not comparable to the flood disasters that took place in western and southern India (for example, in the city of Mumbai alone there was $944 \mathrm{~mm}$ of rainfall in 24 hours which affected 2 million people with at least 200 fatalities) or southern China (heavy rainstorms during the third week of June killing 170 people) in the summer of 2005 [6]. Nonetheless, heavy rain storms in southern Alberta kept thousands of people out of their homes [4], on evacuation alert and left others without electricity for at least five days, particularly during the early June flood [8]. Also, there were major destructions to the region's infrastructure and services. For example, several bridges and roads were damaged; in many towns sewage and water supply systems struggled to cope with the deluge of rain; small businesses were destroyed; and agricultural activities, specifically farm families living on Canada's largest feedlot operations within the region were either flooded or cut off from their neighbors. According to reports, the June $9^{\text {th }}$ rainfall and flooding alone caused over $C \$ 100$ million in damages [8] in southern Alberta, prompting several municipalities to declare states of emergency along the Oldman River, including municipality district (MD) of Pincher Creek, MD of Willow Creek, County of Lethbridge and City of Lethbridge $[3,4]$. In addition to issuing states of emergency, flood warnings and flood watches, on June 9, 2005 the Government of Alberta through Alberta Municipal Affairs implemented a Disaster Recovery Program (DRP) called the 2005 Southern Alberta Disaster Recovery Program (SADRP). SADRP, the largest program of its kind in the province's history [7], was introduced to help residents of this region recover from losses caused from severe rain storms [5, 9]. To date, C\$73.1 million has been paid with an estimated total program cost of C\$162.7 million once final municipal infrastructure and emergency operations costs are received from southern Alberta [7, p. 1]. Based on the above reports, officials have described the 2005 flooding as a "one-in-200 year event" [8].

In addition to the destruction of critical infrastructures, flood-related natural disasters have adverse effects on human health [10-16], particularly among survivors [17] and displaced persons' health [18]. The most common health problems reported among flood victims are: trauma caused by lives lost mainly from drowning [19], increased incidence of infectious diseases, especially acute gastrointestinal infections because of faeco-oral cycling from disruption of sewage disposal $[10,20]$ or untreated sewage disposal [17]; vector-borne and rodent-borne infections, such as malaria, yellow fever, dengue fever, West Nile fever, Hantavirus and leptospirosis $[14,15,19,21]$; wound infections or injuries $[10,22]$; and mental health problems such as anxiety, depression, sleeplessness and post-traumatic stress $[18,21,23]$. In recent years, several studies have been 
conducted to review health impacts of flooding worldwide [10], however, most have focused on developing countries $[10,11]$ and on flooding caused after hurricanes or tropical cyclones $[12,14,17,18]$. The limited literature obtainable on developed countries is primarily from the United States [12, 17], Europe $[18,20]$ and Australia; and there is a deficiency in literature that documents flood-related health issues from rural Canada, especially semi-arid southern Alberta.

In Canada, the few studies available on flood events show that the incidence of waterborne infection is highest in rural areas with intensive agricultural production and especially intensive livestock operations during periods of extreme precipitation [2, 22, 24]. In addition to high incidence level of waterborne infection in rural watersheds [14], recent health reports on Canadians suggests that mental health concerns of farm families [20] and the health status of people who live in rural and remote communities is poorer [25] than the rest of the Canadian population [21, 26], and many have limited access to health care services [27]. However, much of these health studies of Canadians have not included health impacts of flooding. It is well known that individuals living in high or middle income countries who experience natural disasters develop excessive physical, mental and emotional stress [13], especially anxiety and depression [10]. This article explores the health-related impacts of the 2005 flood events on families who reside on large feedlot farms in southern Alberta and also describes the responses to recent flood-related health problems by the feedlot farm families. The specific objectives of this article are to:

- determine the types of health problems experienced by the feedlot farm families living in Lethbridge Northern Irrigation District (LNID);

- examine LNID feedlot farm families' responses to these health problems; and

- identify the most and least helpful types of resources of the participants for coping with flood-related health problems.

\section{Research location and methods}

The purpose of this research was to gain a deeper understanding of the impact of 2005 flood and what resources were most and least helpful to cope with floodrelated health challenges of affected feedlot farm families residing in LNID located in southern Alberta. This research was conducted one month after the September flood and three months after the June flood events. A questionnaire was developed to elicit data with regard to the 2005 flood experiences. For example, the health challenges experienced by the feedlot farm families, their responses associated with these particular flood events, and resources most and least helpful for dealing with flood-related health challenges. This research was approved by the University of Lethbridge Faculty of Arts and Science Ethics Committee. All participants signed informed process consents and confidentiality was maintained.

LNID is located in the southwestern part of the province of Alberta, between the city of Calgary and Lethbridge, and provides water from the Oldman River to 
over 50,000 ha through irrigation canals. The irrigation district's responsibility relates directly to water quantity management through their delivery of water to irrigators and those with whom the district has agreements to supply water. The LNID is home to about 30 of the largest feedlot operations of Canada [28].

Using an interviewer-administered questionnaire, data were collected from a random sample of 33 feedlot owners and/or employees (females $n=8$; males $\mathrm{n}=25$ ) between the ages of 27 and 70 . Feedlot families' contact information was obtained from the LNID office. Most, if not all participants in this research reported living within the LNID during the 2005 flood events. Interviews were conducted from October to December 2005 in the participant's homes lasting 1-2 hours. Finally, all interviews were audio-taped and transcribed verbatim.

\section{Results and discussion}

\subsection{Survey participants}

Sixty feedlot households were contacted, of which 55\% (33/60) consented to participate and were recruited. In this study most participants were male $(76 \%)$ and the median age was in the 40-59 years of age group (Table 1). There was a considerable variation in educational level. The majority of the participants had more than high school education (73\%), were married $(91 \%)$ at the time of interview and more than 58\% said that their household had four or more members. At the time of the 2005 flood, almost all participants (94\%) owned their farm and $79 \%$ of them were engaged primarily in feedlot activities with $67 \%$ managing more than 10,000 beef cattle per year.

Table 1: $\quad$ Background Information of the Participants $(\mathrm{N}=33)$.

\begin{tabular}{|l|c|c|l|c|c|}
\hline Characteristics & N & $\%$ & Characteristics & N & $\%$ \\
\hline Gender & & & Education & & \\
Male & 25 & 76 & High School or $<$ & 27 & 73 \\
Female & 8 & 24 & Post-High School & & \\
\hline Age & & & Main Agricultural Activity & 26 & 79 \\
39 years and $<$ & 8 & 24 & Feedlot & 4 & 12 \\
40 to 59 years & 21 & 64 & Field-crop & 2 & 6 \\
60 years and $>$ & 4 & 12 & Other(dairy \& swine) & & \\
Marital status & & & Farming Status & 31 & 94 \\
Married & 30 & 91 & Owner & 2 & 6 \\
Other & 3 & 9 & Employee & 11 & 33 \\
\hline \# of People live at home & & & Feed Animals per year & 14 & 43 \\
Three or $<$ & 14 & 42 & Less than 10,000 & 5 & 15 \\
Four or $>$ & 19 & 58 & $10,000-20,000$ & 3 & 9 \\
& & & $21,000-30,000$ & & \\
\end{tabular}

\subsection{Flood-related feedlot operation problems}

To assess the impact of flooding on feedlot operations, participants were asked to describe the types of problems they experienced on their feedlot during heavy rainfalls. Almost all participants admitted that the 2005 flood events severely 
damaged their feedlot operation. For example, all talked about how the flooding caused damages to their pens, caused their lagoons to overflow (91\%) and blocked effluent drainage systems $(88 \%)$. In fact, persistent rainfall made it difficult for most to access and clean pens (88\%). In addition to structural damages to pens and lagoons, many talked about loss in animal performance because of flood-related illnesses. Loss of grain, crop damage, loss of bedding supplies, labor shortage and damages to storage and office space were also reported by participants. In fact, the majority of participants talked about their feedlot damages in terms of financial loss. This is because it is the main source of household income for every individual in this study. Moreover, every participant concluded that they will never be able to know their financial loss, and many suggested that they did not want to experience another natural disaster after their experience with BSE crisis.

Table 2: Percentage and types of flood-related problems participants experienced in their feedlot operation during the 2005 flood events.

\begin{tabular}{|l|c|}
\hline Types of Problems & Respondents \\
\hline Experienced & \% Indicated \\
\hline Wastewater \& Flood Runoff Management & 97 \\
-Pen Problems (i.e. overflow, messy, damaged, etc.) & 91 \\
-Lagoon Overflow & 88 \\
-Access & 88 \\
-Equipment problems (i.e. destroyed from the flood, not & \\
available or accessible) & 88 \\
-Drainage Problem & 79 \\
-Lagoon Full & 97 \\
\hline Animal Health, Illness \& Death & 97 \\
-Animal Illness (primarily foot rot) & 67 \\
-Animal Performance & 94 \\
-Loss of Animal & 85 \\
\hline Animal Feed \& Bedding Supplies & 79 \\
-Crop Damage (i.e. forages) & 70 \\
-Animal Feed loss & 94 \\
\hline -Grain loss & \\
\hline Labour Issues & \\
\hline Damages to Storage \& Office Space & \\
\hline
\end{tabular}

\subsection{Health challenges}

Previous studies provide detailed accounts of the impact of floods on human health from waterborne diseases to mortality $[10,13,15,17,19,21]$. Table 3 displays the types of health challenges experienced by the participants and their family members. While flood-related diseases were reported by $3 \%$ of 
participants and $12 \%$ of family members, flood-related mental health problems were reported by $63 \%$ of participants and $58 \%$ of family members. The most common mental problem by both the participants and family members are: stress $(85 \%)$, anxiety (85\%), anger (67\% and 64\%), and helplessness $(73 \%$ and $58 \%)$. Only a minority $(6 \%)$ of participant believed that they alone experienced depression. Social and behavioral problems, including isolation and helplessness, were experienced by $40 \%$ of participants and $24 \%$ of family members.

Though the majority of participants and their family members experienced mental health concerns, only $9 \%$ of participants accessed health services. Family physicians, counselors, and psychologists were most commonly sought in addressing theses concerns. Counseling services and medical treatments were utilized most frequently. No differences in health service utilization pattern were observed based on age, education or farm size. However, the findings somewhat supports earlier data on rural Canadians underutilization of health services as a group $[25,27,29,30]$. This may have some adverse long term health consequences on the flood-affected individuals.

Table 3: Percentage and types of health challenges experienced by the participants and their family members during the 2005 flood.

\begin{tabular}{|l|c|c|}
\hline Flood-Related Health Challenges & Participants & Family Members \\
\hline Experienced & \% Affected & \% Affected \\
\hline Medical Problems & 3 & 12 \\
Disease & & \\
\hline Physical Problems & 73 & 42 \\
-Tired & 64 & 36 \\
-Sore back & & \\
\hline Mental/Emotional & 85 & 85 \\
-Stress & 85 & 85 \\
-Anxiety & 67 & - \\
-Anger & 6 & 58 \\
-Depression & 73 & 15 \\
-Helplessness & 18 & 33 \\
\hline Social/Behavioral & 61 & \\
-Isolation & & \\
-Sleeplessness & & \\
\hline
\end{tabular}

\subsection{Behavioral response}

The cultural characteristics of rural and remote communities influence the experience of natural disaster management. Similar to previous studies concerning the health of rural Canadians, this study explored what resources the participants found to be most and least helpful in dealing with their health issues related to the 2005 flood events. Most participants (91\%) reported that the family or a family member was a helpful source of support in dealing with flood-related health challenges, followed by friends (64\%), neighbors $(42 \%)$, church $(39 \%)$ 
and employees (36\%). In other words, the participants found that their communities were more helpful in assisting participants to deal with their floodrelated health problems than public and service delivery groups.

Resources that were noted as least helpful included Natural Resource Control Board (36\%), a regulatory body that is responsible for the management of Intensive Livestock Operations in the province. Similarly, 33\% did not find LNID very useful during the recent flooding, followed by the County of Lethbridge (30\%) and media (21\%).

Table 4: $\quad$ Resources most and least helpful to the participants while dealing with 2005 flood-related health issues.

\begin{tabular}{|l|c|c|}
\hline Type of Resources & $\begin{array}{c}\text { Most } \\
\text { Helpful }\end{array}$ & Least Helpful \\
\hline Community Categories & $(\%)$ & $(\%)$ \\
\hline Family & 91 & 3 \\
\hline Friends & 64 & 0 \\
\hline Neighbors & 42 & 27 \\
\hline Staff/Employees & 36 & 15 \\
\hline Church & 39 & 0 \\
\hline Other Resources - i.e. Sports, Casino, etc. & 21 & 6 \\
\hline Public \& Service Delivery Group & 3 & 27 \\
\hline Public ${ }^{1}$ & 42 & 6 \\
\hline Industry ${ }^{2}$ & 21 & 0 \\
\hline Insurance \&telephone Companies & 12 & 36 \\
\hline Natural Resource Control Board (NRCB) & 18 & 33 \\
\hline $\begin{array}{l}\text { Lethbridge Northern Irrigation District } \\
\text { (LNID) }\end{array}$ & 24 & 30 \\
\hline County of Lethbridge (CL) & 3 & 21 \\
\hline All levels of Government & 6 & 0 \\
\hline Researcher & \multicolumn{2}{|l}{} \\
\hline Information Technology & 6 & 21 \\
\hline $\begin{array}{l}\text { Media (i.e. television, newspaper, internet \& } \\
\text { radio) }\end{array}$ & $\begin{array}{l}{ }^{1} \text { Public = people who do not live on farms; }{ }^{2} \text { Industry }=\text { Livestock and Cattle } \\
\text { Producers. }\end{array}$ \\
\hline
\end{tabular}

\section{Conclusion}

This research is the first to investigate the types of health challenges faced by feedlot farm families during the 2005 flood in southern Alberta. The results of this research are highly relevant for future research that addresses the public health impacts following flooding in livestock intensive areas. For instance, although the participants lived in an intensive livestock community, they 
reported relatively low levels of immediate, short- or long-term infectious disease effects or occurrence of clinically relevant pathology. Instead, the majority of participants experienced some form of mental/emotional health problems. Furthermore, the results demonstrate that the participants and their family members found their community to be most helpful, and the service delivery sector and the mass media the least helpful resources. This may be due to the duration and severity of flood-related health problems, access to service facilities, or the stigma associated with mental health challenges. Further research is needed to identify factors associated with under-utilization of service delivery. One limitation associated with the present study is that the findings are based on only one livestock sector and only one irrigation district in southern Alberta. It would be interesting to know if the findings would be similar in other livestock sectors, irrigation districts and regions within the province of Alberta. Additional studies are planned to investigate these issues.

\section{Acknowledgements}

The authors thank Alberta Ingenuity Centre for Water Research (AIWRC) for the financial support to carry out this research project and LNID office for providing the contact information of the feedlot farm families. We also thank all the participants who gracefully and freely shared their experiences with the interviewer.

\section{References}

[1] Government of Alberta. Alberta, www.en.wikipedia.org/wiki/Alberta, 2006.

[2] Hyland, R., J. Byrne, Selinger, B., Graham, T., Thomas, J., Townshend, I. \& Gannon, V. Spatial and temporal distribution of faecal indicator bacteria in southern Alberta, Canada. Water Quality Research Journal of Canada, 38, pp. 15-32, 2003.

[3] Alberta Environment. June 2005 Flood Events in Albert. Presentation to the Alberta Environment Conference, 2006.

[4] Carpenter, G., Floods in Alberta, Canada. Report Date, $30^{\text {th }}$ June 2005 , www.guycarp.com

[5] Government of Alberta. Disaster Recovery Programs are available on the Municipal Affairs, www.municipalaffairs.gov.ab.ca, 2006.

[6] World Meteorological Organization (WMO). WMO Statement on the Status of the Global Climate in 2005, World Meteorological Organization: Geneva, Switzerland, 2005.

[7] Alberta Municipal Affairs. Flooding in Alberta in 2005 - An Overview. Alberta Municipal Affairs: Edmonton, Alberta, 2006.

[8] Canadian Broadcasting Corporation (CBC). 2005 sets rain and flood records. $\quad C B C$ News, www.cbc.ca/canada/story/2005/12/29/weatherrecords051229.html, 2005. 
[9] Alberta Agriculture, Food and Rural Development. 2005 Alberta Disaster Recovery Program - Flooding Component, Government of Alberta: Edmonton, Alberta, 2005.

[10] Ahern, M., Kovats, R. S., Wilkinson, P., Roger, F. \& Matthies, F., Global health impacts of floods: Epidemiologic evidence. Epidemiologic Reviews, 27, pp. 36-46, 2005.

[11] Bissell, R., Delayed-impact infectious disease after a natural disaster. The Journal of Emergency Medicine, 1, pp. 59-66, 1983.

[12] Diaz, J. H., The public health impact of hurricanes and major flooding. The Journal of the Louisiana State Medical Society, 156(3), pp. 145-50, 2004.

[13] Greenough, G., McGeehin, M., Bernard, S. M., Trtanj, J., Riad, J. \& Engelberg, D., The potential impacts of climate variability and change on health impacts of extreme weather events in the United States. Environmental Health Perspectives, 109(2), pp. 191-198, 2001.

[14] Gubler, D. J., Reiter, P., Ebi, K. L., Yap, W., Nasci, R. \& Patz, J. A., Climate variability and change in the United States: Potential impacts on vector and rodent-borne diseases. Environmental Health Perspectives, 109(2), pp. 223-233, 2001.

[15] Ivers, L. C. \& Ryan, E. T., Infectious diseases of severe weather-related and flood-related natural disasters. Current Opinion in Infectious Diseases, 19, pp. 408-414, 2006.

[16] Rose, J. B., Epstein, P. R., Lipp, E. K., Sherman, B. H., Bernard, S. M. \& Patz, J. A., Climate variability and change in the United States: Potential impacts on water and foodborne diseases caused by microbiologic agents. Environmental Health Perspectives, 109(2), pp. 211-221, 2001.

[17] Reacher, M., McKenzie, K., Lane, C., Nichois, T., Kedge, I., Iversen, A., Hepple, P., Walter, T., Laxtn, C. \& Simpson, J., Health impacts of flooding in Lewes: A comparison of reported gastrointestinal and other illness and mental health in flooded and non-flooded households, Communicable Disease and Public Health, 7(1), pp. 39-46, 2004.

[18] Keene, E. P., Phenomenological study of the North Dakota flood experience and its impact on survivors' health. International Journal of Trauma Nursing, 4(3), pp. 79-84, 1998.

[19] Vasconcelos, P., Flooding in Europe: A brief review of the health risks. Eurosuveillance, 11(4), www.eurosurveillance.org/ew/2006/060420.asp, 2006.

[20] Schmidc, C. W. Lessons from the flood: Will Floyd change livestock farming? Environmental Health Perspectives, 108(2), pp. A74-A77, 2000.

[21] Ohi, A. \& Tapsell, S., Flooding and human health: The dangers posed are not always obvious. British Medical Journal, 321, pp. 1167, 2000.

[22] Health Canada. Notifiable diseases annual summary. Canada Communicable Disease Report, 27, pp. 2765, 2001.

[23] World Health Organization and Unicef. Water for Life: Making it Happen, WHO/UNICEF Joint Monitoring Programme for Water Supply and Sanitation, France, 2005. 
[24] Gannon, V. P. J., Graham, T. A., Read, S., Ziebell, K., Muckle, A., Mori, J., Thomas, J., Selinger, B., Townshend, I. \& Byrne, J. Bacterial pathogens in Southern Alberta, Canada. Journal of Toxicology and Environmental Health Part A, 67, pp. 1643-1653, 2004.

[25] Leiper, B. D., Rural women's health issues in Canada: An overview and implications for policy and research. Canadian Women's Studies, 24(4), pp. 109-121, 2005.

[26] DesMeules, M., Pong, R., Lagacé, C., g, D., Manuel, D., Pitblado, R., Bollman, R., Guernsey, J., Kazanjian, A. \& Koren, I. 2006. How healthy are rural Canadians? Canadian population health initiative, Canadian Institute for Human Information, Ottawa, 2006.

[27] Romanow, R., Building on values: The future of health care in Canada, Ottawa: The Romanow Commission Report, 2002.

[28] North American Environmental Law and Policy (NAELP). Comparative Standards for Intensive Livestock Operations in Canada, Mexico and the United States, Ếditions Yvon Blais: Montreal, 2003.

[29] Thomlinson, E., McDonagh, M. K., Crooks, K. B. \& Lees, M., Health beliefs of rural Canadians: Implications for practice. Australian Journal on Rural Health, 12, pp. 258-263, 2004.

[30] Thurston, W., E., Glundell-Gosselin, H. J. \& Pose, S., Stress in male and female farmers: An ecological rather than an individual problem. Canadian Journal of Rural Medicine, 8(4), pp. 247-254, 2003. 